\title{
Innovative approach to nutrition of patients in intensive care unit
}

\author{
Yoğun bakım ünitesinde bulunan hastaların beslenmesinde yenilikçi yaklaşım
}

\author{
Hatice Dolker (iD, Emel Yıldız $\mathbb{D}$, Ramazan Küçük (D) \\ Department of Obstetrics and Gynecology, İstanbul Bilim University Avrupa Hospital, İstanbul, Turkey
}

\begin{abstract}
Enteral nutrition is defined as the continuous or intermittent delivery of nutrients through nasoenteric (nasogastric, nasojejunal) gastrostomy, or jejunostomy when gastrointestinal system functions are normal. In enteral nutrition, nutrients may be administered continuously or intermittently. Continuous feeding is the continuous delivery of food using an infusion pump. Intermittent feeding is the delivery of food to the patient as bolus over a short time period via large-diameter syringe or gravity drip through a hanging food bag. Continuous feeding is recommended because it reduces gastrointestinal complications and is easily administered. This article aims to describe an alternative method to the feeding bag for the nutrition of patients treated at the Intensive Care Unit of the Evliya Celebi Training and Research Hospital of Kutahya Health Sciences University.

Keywords: Innovation, intensive care unit, nutrition.
\end{abstract}

öz

Enteral beslenme, gastrointestinal sistem fonksiyonlarının normal veya normale yakın olması durumunda, besinlerin nazoenterik (nazogastrik, nazojejunal), gastrostomi veya jejunostomi yoluyla devamlı ya da aralıklı olarak hastaya verilmesi olarak tanımlanmaktadır. Enteral beslenmede besinler sürekli ya da aralıklı olarak uygulanabilir. Sürekli beslenme, infüzyon pompası kullanılarak besinin sürekli verilmesidir. Aralıklı beslenme, besinin hastaya bolus olarak damlatılarak veya asılı besin torbası aracılığıyla yer çekiminin etkisiyle büyük çaplı enjektörle kısa sürede verilmesidir. Gastrointestinal komplikasyonları azalttığı ve uygulanmasının kolay olmasından dolayı sürekli beslenmenin kullanımı önerilmektedir. Bu makalede Kütahya Sağlık Bilimleri Üniversitesi Evliya Çelebi Eğitim ve Araştırma Hastanesi Yoğun Bakım Ünitesinde tedavi gören hastaların beslenmesinde beslenme torbasına alternatif olarak uygulanan yöntemin anlatılması amaçlanmıştır.

Anahtar sözcükler: Innovasyon, yoğun bakım ünitesi, beslenme.

Patients in intensive care are especially prone to developing protein-energy malnutrition. Development of protein-energy malnutrition paves the way for complications such as nosocomial infections and multiple organ failure. This condition causes prolonged intensive care stay, as well as increased morbidity and mortality.

Studies in the literature have reported that initiation of nutrition support in intensive care patients within 24-48 hours improved clinical outcomes, accelerated the wound healing process, reduced infection rates, and shortened hospitalization period. ${ }^{[1-3]}$ Therefore, nutrition support is a routine necessity in intensive care treatment and has a vital role in the prevention of malnutrition and treatment of patients. ${ }^{[4]}$

In patients undergoing the decision to receive nutrition support, calorie needs should be calculated and the route of administration must be determined. According to the patient's condition, nutrition is provided via enteral/parenteral route. In the absence of contraindications, the physiological nutritional method, the enteral route, is recommended. ${ }^{[5]}$

\section{Received: August 07, 2019 Accepted: October 23, 2019 Published online: March 16, 2020}

Correspondence: Emel Yıldız, MD. Kütahya Sağlık Bilimleri Üniversitesi Evliya Çelebi Eğitim ve Araştırma Hastanesi, Anesteziyoloji ve Reanimasyon Kliniği, 43040 Kütahya, Türkiye. Tel: +90 505 - 9577041 e-mail: dremelyldz@gmail.com 
Enteral nutrition is defined as the continuous or intermittent delivery of nutrients through nasoenteric (nasogastric, nasojejunal) gastrostomy or jejunostomy, when gastrointestinal functions are normal or close to normal. ${ }^{[6]}$ Administration through this route provides the continuation of intestinal physiology and bile secretion, prevents the development of intestinal villi atrophy and stress ulcers, secures secretory immunoglobulin A, protects intestinal lymphoid tissue, increases blood flow in the spleen, reduces catabolic response to trauma, and prevents bacterial translocation and septic complications. ${ }^{[7]}$

Food can be delivered continuously or intermittently in enteral nutrition. ${ }^{[8]}$ Continuous nutrition is the continuous delivery of food using an infusion pump. It has advantages such as reducing the risk of aspiration, controlled delivery of food to the intestines, and increased control of blood glucose level. The remaining time of the food left in the closed system is maximum 24 hours, in the open system eight hours. Therefore, there is a disadvantage such as causing the remaining food to be discarded. In addition, it requires another follow-up disadvantage. ${ }^{[8]}$ Food can remain in the for maximum 24 hours in the closed system, and maximum eight hours in the open system. Therefore, it has the disadvantage of the remaining food being thrown away. Another disadvantage is that it requires continuous surveillance. ${ }^{[8]}$

Intermittent feeding is the delivery of food to the patient as bolus over a short period ( 5 minutes or more) via a large-diameter syringe or gravity drip through a hanging food bag. Advantages include rapid delivery of nutrients, no requirement of infusion pump, and relaxation of the stomach between feeding. However, its disadvantages include higher rate of side effects, use in only gastric feeding, and spending more of the nurse's time compared to continuous feeding. ${ }^{[8]}$

Studies in the literature recommend the use of continuous feeding due to less complications and ease of application. ${ }^{[9,10]}$

Nurses are among healthcare professionals who are responsible for patient nutrition. According to the Turkish Ministry of Health Nursing Regulations (2010), "the nurse is responsible for determining the nutritional needs of patients (enteral and parenteral nutrition), planning and implementing nursing care according to these needs, and sterilization of devices used for nutrition". ${ }^{[11]}$

Nowadays, increased expectations in services, rapid progression of information and technology, the need for adaptation, global competition, and increased cost of health care services has made innovation in nursing mandatory. The concept of innovation in nursing are practices that enable the development of new ideas, methods and tools for eliminating patient needs, reducing the cost of services, and increasing efficiency in the nursing profession. ${ }^{[12]}$

Innovation in the field of nursing is vital to the development and maintenance of quality of care because nursing care is significant to the health system. Nurses must know what they are doing, why they are doing it, and the scientific basis of their practice. At the same time, they are responsible for the service they provide, questioning whether or not it is appropriate and effective, as well as conducting research to determine how and in what manner it can be provided for it to be more effective, of higher quality, and less costly. ${ }^{[13]}$

This study aimed to describe an alternative method to the feeding bag for the nutrition of patients treated at the Intensive Care Unit of the Evliya Celebi Training and Research Hospital of Kutahya Health Sciences University.

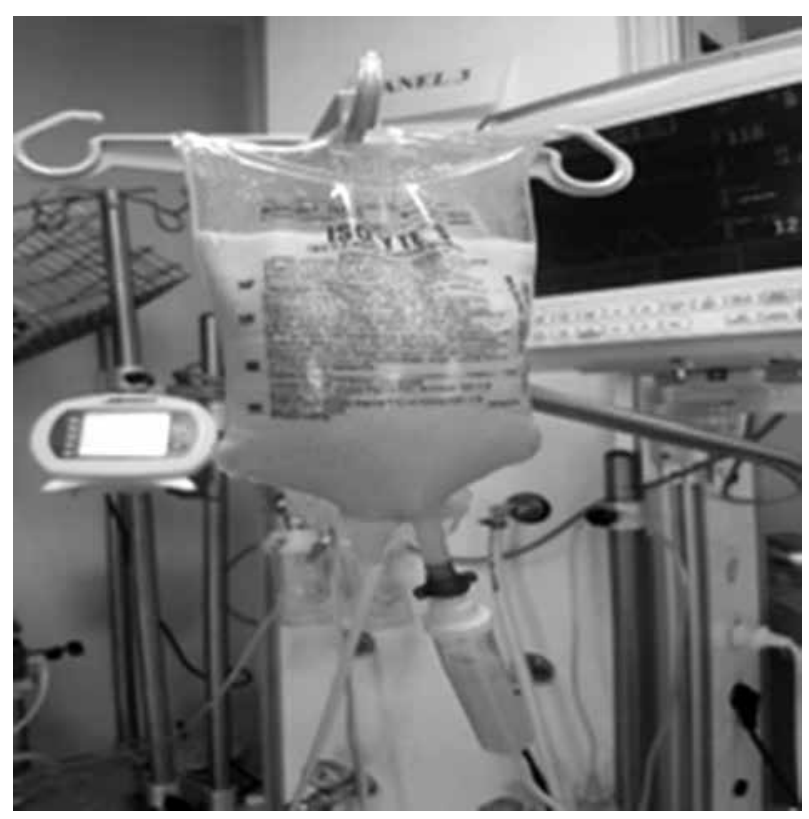

Figure 1. Filling an empty fluid bag with feeding solution. 
Patients in the intensive care unit are fed with continuous or intermittent nutrition, depending on treatment protocol. However, in some cases, feeding bags may be unavailable due to the hospital's economic conditions. In this case, bolus (intermittent) nutrition is preferred for feeding the patient rather than continuous nutrition which is more advantageous in terms of side effects. Nurses working in the intensive care unit developed a less costly method that does not require feeding bag. This method consists of adding feeding solution to an empty saline bag, allowing it to function as a feeding bag (Figure 1).

With this method, nurses can reuse empty unused saline bags, eliminating the need for an extra feeding bag for nutrition, and contributing to lowering hospital expenses. In addition, the continuity of the patient's treatment is ensured by utilizing all available means.

In conclusion this innovative method is a novel idea that is feasible, inexpensive, and within the scope of patient and employee safety. It also saves time and labor in nursing care.

\section{Declaration of conflicting interests}

The authors declared no conflicts of interest with respect to the authorship and/or publication of this article.

\section{Funding}

The authors received no financial support for the research and/or authorship of this article.

\section{REFERENCES}

1. Dominioni L, Rovera F, Pericelli A, Imperatori A. The rationale of early enteral nutrition. Acta Biomed 2003;74:41-4.
2. Mazuski JE. Feeding the injured intestine: enteral nutrition in the critically ill patient. Curr Opin Crit Care 2008;14:432-7.

3. Barr J, Hecht M, Flavin KE, Khorana A, Gould MK. Outcomes in critically ill patients before and after the implementation of an evidence-based nutritional management protocol. Chest 2004;125:1446-57.

4. Çekmen N, Dikmen E. Yoğun bakım hastalarında enteral ve parenteral nütrisyon. Toraks Cerrahisi Bülteni 2014;5:187-97.

5. Roberts P, Zolaga G. Enteral nutrition. In: Rippe J, Irwin $\mathrm{R}$, Albert J, Fink M, Intensive Care Medicine. 2th ed. USA: Litthle Brown and Company; 2003. p. 875-98.

6. Tekin E. Enteral beslenme uygulanan yoğun bakım hastalarında rutinde kullanılan iki farklı izlem protokolünün değerlendirilmesi [Uzmanlik Tezi], İzmir: Dokuz Eylül Üniversitesi Tip Fakültesi Anesteziyoloji ve Reanimasyon Anabilim Dalı; 2015.

7. Koçhan E. Hemşirelerin parenteral ve enteral beslenme uygulamalarına ilişkin bilgi düzeylerinin değerlendirilmesi [Yüksek Lisans Tezi], İstanbul: Demiroğlu Bilim Üniversitesi Sağlık Bilimleri Enstitüsü Hemşirelik Anabilim Dalı İç Hastalıkları Hemşireliğ̆i Yüksek Lisans Programı; 2018.

8. Gürkan A, Gülseven B. Enteral beslenme: bakımda güncel yaklaşımlar. Anadolu Hemşirelik ve Sağllk Bilimleri Dergisi 2013;16:116-22.

9. Williams TA, Leslie GD. A review of the nursing care of enteral feeding tubes in critically ill adults: part I. Intensive Crit Care Nurs 2004;20:330-43.

10. Bourgault AM, Ipe L, Weaver J, Swartz S, O'dea PJ. Development of evidence-based guidelines and critical care nurses ' knowledge of enteral feeding. Crit Care Nurse 2007;27:17-22.

11. Özbaş N, Baykara ZG. Hemşirelerin tüple enteral beslenme konusunda bilgi düzeylerinin belirlenmesi. Journal of Human Sciences 2018;15;359-67.

12. Kartal H, Kantek F. Hemşirelikte inovasyon örnekleri. Journal of Health and Nursing Management 2018;5:57-63.

13. Dil S, Uzun M, Aykanat B. Hemşirelik eğitiminde inovasyon. International Journal of Human Sciences 2012;2:1217-28. 